\title{
A Genuine Collaboration in Text and Music: L'Enfant et les sortilèges (The Child and the Enchantments)
}

\author{
Susan Yuan Wen Nheu
}

\section{Abstract}

L'Enfant et les sortilèges is a lyric fantasy in one act by French composer Maurice Ravel and French writer and librettist Sidonie-Gabrielle Colette. This work, one of Ravel's two contributions to the lyric stage, was first performed at Monte Carlo on 21 March 1925 and, one year later, it premiered at the Opèra-Comique in Paris. Sparsely documented communication and personal contact in the nine years between the work's conception and premiere seems to indicate that there was little collaboration on the work. Through a study of primary and secondary sources and an examination of the strong text-music relationship, however, I argue that L'Enfant was in fact the result of a genuine collaboration between Colette and Ravel. My argument is supported by a study of the genesis of the opera, Ravel's manipulation of the rhymes and rhythms of Colette's libretto, the relationship the work has with fairytale narratives and storytelling, and Ravel's unique compositional technique.

The text and music in $L^{\prime} E n f a n t$ et les sortilèges is the result of one of the greatest collaborations of the 1920s. This work is a lyric fantasy in one act and is one of Maurice Ravel's two contributions to the lyric stage. It was first performed at Monte Carlo on 21 March 1925 under the baton of Victor de Sabata; one year later, it premiered at the Opèra-Comique in Paris. ${ }^{1} L^{\prime} E n f a n t$ is the story of a rude and disrespectful child who disobeys his mother's wishes and goes on a destructive rampage in his room. The cast includes fairytale characters, crockery, furniture, a homework book, plants and small animals, which come to life to reprimand the child who has been tormenting and hurting them. Through his spiritual journey, the child experiences love, friendship and forgiveness as he develops his moral compass and awareness of the consequences of his behaviour. At a time when successful collaborations between composers and

1 Rollo H. Myers, Ravel: Life and Works, London: Duckworth, 1971, pp. 207-08. 
writers of stature were surprisingly rare, ${ }^{2} L^{\prime}$ Enfant was unique in pairing the most acclaimed living composer in France, Ravel, ${ }^{3}$ with Sidonie-Gabrielle Colette, ${ }^{4}$ a French writer who was equally recognised as one of the finest of her generation', to create an opera-ballet set to a new libretto. ${ }^{5}$ During the nine years between the work's conception and premiere (1916-25), the dearth of documented communication between the composer and librettist gives rise to the idea that there was little or no truly 'collaborative' process in the preparation of $L^{\prime}$ Enfant. ${ }^{6}$ Through exploring the genesis of the opera, Ravel's manipulation of the rhymes and rhythms of Colette's libretto, the relationship the work has with fairytale narratives and Ravel's compositional technique, I argue that, in contrast, despite having worked mostly independently, Ravel and Colette were genuine collaborators.

Understanding the genesis of $L^{\prime} E n f a n t$ illuminates the events and circumstances of the composer's life, which interrupted and delayed L'Enfant's composition. The genesis of the opera can be traced back to World War I. ${ }^{7}$ In 1916, Jacques Rouché, director of the Opéra Garnier, approached Colette with a commission for a libretto of a 'fairy-ballet' ${ }^{8}$ Following Colette's agreement to write the libretto, and having been turned down by composer Paul Dukas, Rouché approached Ravel with the commission. Colette sent Ravel a script in late 1916 while he was stationed at Verdun, but, as a result of the outbreak of war, it did not reach him. ${ }^{9}$ Despite this first delay, Ravel eventually received the draft of

2 Emily Kilpatrick, 'Enchantments and Illusions: Recasting the Creation of L'Enfant et lest sortileges', in Deborah Mawer, Ravel Studies, Cambridge University Press, 2010, p. 31.

3 French composer Maurice Ravel (1875-1937) was one of the most original and sophisticated musicians of the early 20th century. He was a master of orchestral and pianistic tone colour. Although he is often described as an 'impressionist' and paired with his contemporary, Claude Debussy, Ravel does not fit neatly into any musical style category - 'much of his music is too clearly defined in form and tonality and classically balanced in phrase structure to be considered impressionist'. Roger Kamien, Music An Appreciation, New York: McGraw-Hill, 2004. Barbara L. Kelly, 'Ravel, (Joseph) Maurice', Grove Music Online, Oxford Music Online, Oxford University Press, accessed 29 October 2013, http://www.oxfordmusiconline.com/subscriber/ article/grove/music/52145.

4 French writer Sidonie-Gabrielle Colette (1873-1954) became well-known in Parisian musical circles after her marriage to the music critic known as Willy (Henri Gauthier-Villars). According to The New Grove Dictionary of Opera, "her "Claudine" novels - which Willy published under his own name - created a vogue, one result of which was the operetta Claudine by Rodolphe Berger.' Colette also worked as a music critic, and on several occasions she was sent to the same concert as Debussy to produce a different viewpoint. Richard L. Smith, 'Colette', The New Grove Dictionary of Opera, Grove Music Online, Oxford Music Online, Oxford University Press, accessed October 29, 2013, http://www.oxfordmusiconline.com/subscriber/article/ grove/music/O005396.

5 Kilpatrick, 'Enchantments and Illusions', p. 31. ('Libretto' refers to 'the name generally given to the book of the words of an opera, or other vocal dramatic work, and consequently to the text itself. The term has been current in English since about the mid-18th century.' John Warrack \& Kenneth Chalmers, 'libretto', The Oxford Companion to Music, Oxford Music Online, Oxford University Press, accessed 29 October 2013, http:// www.oxfordmusiconline.com/subscriber/article/opr/t114/e3957.).

6 Myers, Ravel: Life and Works, pp. 57-58.

7 Arbie Orenstein, Ravel: Man and Musician, New York: Columbia University Press, 1975, p. 78.

8 Kilpatrick, 'Enchantments and Illusions', p. 32.

9 Richard L. Smith, 'Ravel's Operatic Spectacles', in Jonathan Cross \& Deborah Mawer, The Cambridge Companion to Ravel. New York: Cambridge University Press, 2000, p. 203. 
the libretto in $1918,{ }^{10}$ however, there is no record of him working with it until 1920. ${ }^{11}$ According to the first known direct communication between Ravel and Colette, ${ }^{12}$ another delay was Ravel's poor health. 'My only excuse,' Ravel wrote, 'is the state of my health: for a long time, I feared that I would never be able to do anything.' ${ }^{\prime 3}$

Furthermore, following the death of Ravel's mother in January 1917, ${ }^{14}$ he was in no state to undertake a major project. ${ }^{15}$ This period of grief marked a turning point in Ravel's career, according to Arbie Orenstein:

its immediate effect was some three years of virtual silence with regard to composition and from this point until his swan song ... only about one composition a year would be completed. ${ }^{16}$

It is, therefore, evident that Ravel's life circumstances delayed L'Enfant's composition.

Primary sources reveal that a collaborative approach towards L'Enfant was in existence from the very beginning and the artists developed a shared understanding on the project. The correspondence between Ravel and Colette is evidence of an exchange of ideas. For example, when Ravel asked, 'What would you think of the cup and teapot, in old Wedgwood - black — singing a ragtime?', Colette responded, 'Why certainly a ragtime! Why of course Negroes in Wedgwood!' It is clear that Ravel valued Colette's input and ideas when he states, 'I would be grateful to have your opinion on these two points ...'. One week following Ravel's letter, Colette wrote in her return letter that 'the squirrel will say everything you wish'. She also seeks for Ravel's artistic judgment, 'Does the "cat" duo, exclusively meowed, please you?'. ${ }^{17}$ A spirit of camaraderie, collaborative enthusiasm and a shared sense of artistic sympathy between Ravel and Colette is unmistakeable in their correspondence.

The word and essence of collaboration carries on throughout their correspondence. The choice of language employed by both Ravel and Colette conveys a sense of artistic partnership: 'our opera'; ${ }^{18}$ refers to the existence of a collaboration: 'to see if she still wants to have me as a collaborator'; ${ }^{19}$ and

10 Kilpatrick, 'Enchantments and Illusions', p. 36.

11 Orenstein, Ravel, p. 78.

12 Kilpatrick, 'Enchantments and illusions', p. 36.

13 Arbie Orenstein, A Ravel Reader: Correspondence, Articles, Interviews, Mineola, New York: Dover Publications, 2003, p. 188. Refer to appendices A and B.

14 Kilpatrick, 'Enchantments and illusions', p. 34.

15 ibid.

16 Orenstein, Ravel: Man and Musician, p. 75.

17 Orenstein, A Ravel Reader, p. 188.

18 ibid.

19 Kilpatrick, 'Enchantments and Illusions', p. 37. 
is punctuated with words of encouragement and support for each other's roles: 'Go for it!'. ${ }^{20}$ It is clear that the artists intended L'Enfant to be a shared project and that Ravel and Colette clearly supported and respected each other's roles as collaborators. Despite the events and circumstances that delayed the composition, the primary sources are explicit in revealing that Ravel and Colette agreed to work on L'Enfant as a collaborative project from the very beginning.

Ravel and Colette shared an artistic affinity for the interplay of music and language. As a composer, Ravel gave much consideration to the words in L'Enfant through his manipulation of the rhythms and resonances of the language; he heightened the dramatic and musical effects of Colette's words. Ravel's input in linguistic effect can be seen in the textual coherence between the contrasting episodes in the opera. From the beginning to the last scene, the same poetic gesture is used to generate the same distinctive effects creating subtle onomatopoeia. As observed by Marie-Pierre Lussus, "many characters of the individual "enchantments" ("sortileges") are all shaped by the sounds of their words as much as by their meanings' ${ }^{21}$ An example is the grouping of the vowel and consonant sounds of the sortilèges into two categories to emphasise the differences between the 'hard' and 'soft' sounds. The princess, the cats, the dragonfly and the squirrel are grouped in the 'soft' sound category while the other sortilèges - the child's opening monologue, the clock, the arithmetic scene, the fire and the teapot have 'hard' vowel and consonant sounds. For example, the 'hard' sounds are represented by the child singing ' $J$ 'ai pas envie de faire mapage', and by the teapot in the opening scene with the line 'Black and costaud, black and chic $\ldots{ }^{\prime},{ }^{22}$ while the 'soft' sounds, such as $\mathrm{b} / \mathrm{d} / \mathrm{g}$, the fricative $\mathrm{z}$ [rose], $\varepsilon$ [aime and cherche], and the slow $\theta$ [jeu], are used in the libretto sung by the dragonfly. As seen in Appendix D, the contrast between these two linguistic affects can be seen from the libretto of the fire and the dragonfly:

The fire

Je rechauffe les bons; Je brûle les méchants; Petit barbare, barbare imprudent; Tu as insultéàtous les dieux bienveillant; Quitendent entre le malheur et toi; Le fragile barrière! ...; Gare au feu dansant!; Gare, gare, gare, gare à toi! ${ }^{23}$

20 Orenstein, A Ravel Reader, p. 188.

21 Kilpatrick, 'Enchantments and Illusions', p. 41.

22 ibid., p. 37.

23 Emily Kilpatrick, “'Jangling in Symmetrical Sounds”: Maurice Ravel as Storyteller and Poet', Music Council of Australia, 1 (2009), p.11. Refer to Appendix C. 
The dragonfly

Où es tu?; Je te cherche; Le filet; Il t'a prise; O toi chère; Longue et frèle; Tes turquoises; Tes topazes; L'air qui t'aime; Les regretted; Moins que moi ... ${ }^{24}$

The subtle onomatopoeia achieved through the emphasis and juxtaposition of 'hard' and 'soft' vowel and consonant sounds gives the sortilèges an additional depth of character. ${ }^{25}$ Clearly, Ravel gave much consideration to the words in L'Enfant and he manipulated the qualities of Colette's text to maximise both its aural and dramatic effects in the opera. ${ }^{26}$

Furthermore, given Colette's training as a pianist in her youth and her work in musical criticism for example, of Gil Blas, ${ }^{27}$ her musical background was certainly a factor contributing to the development of a smooth prosaic style, which played with the expression of rhythm and assonances. ${ }^{28}$ Considering Colette's musical background, L'Enfant's textual coherence matches well with a poet who plays with words and sounds to bring out the dramatic effects of Ravel's music. As we see in the authorship of the lines and phrases, L'Enfant exudes a strong sense of artistic affinity between composer and librettist through its musical and poetic interplay. As observed by Raymond Balliman, the text and music of L'Enfant were so intertwined that it is impossible to separate the collaborators' ${ }^{29}$ Ravel and Colette shared a truly interdisciplinary sense of what an operatic libretto might be in L'Enfant, where the words were shaped by musical sense and music by textual sonorities. ${ }^{30}$

The fantasy and fairytale theme of L'Enfant suggests that, through the expressive use of language, Ravel and Colette were deliberately aligning music and text with the tradition of storytelling, a genre defined by the sounds of the spoken word. ${ }^{31}$ Many of the hallmarks of the fairytale narrative are present in L'Enfant: 'a timeless setting; unnamed characters (the child, the fire, the princess), reciprocal events and actions (the destructive child is himself injured and becomes "good"), a happy ending that suggests a clear moral, and a narrative shaped by "magical" events'. ${ }^{32}$ L'Enfant's connection to storytelling further supports the strong text-music relationship and collaborative nature of the work. Ravel and Colette were clearly aware of the subtleties of sounds

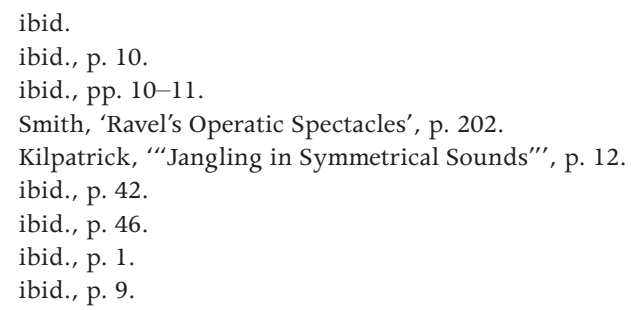


and language in their respective métier and, through their collaborative efforts, they acted as storytellers to achieve the regular and natural rhythmic patterns, illustrative rhymes and assonances, and expressive inflections characteristic of fairytale narratives. An example can be seen in the 'Cats' Duet', for which Ravel contributes to the phonetic representation of the cats mating scene ' $\mathrm{maou}^{\prime 33}$ and also in the croaking frog's line 'Kékékékécékéça' in the garden scene. ${ }^{34}$ Through the expressive use of language combined with musical effect, Ravel and Colette worked together to achieve a sense of storytelling in $L^{\prime} E n f a n t$.

Collaboration on L'Enfant is also demonstrated by the relationship between Ravel's composition technique and its function in assisting with the communication of Colette's text. Throughout the opera, as seen in the development of the main protagonist (the child), Ravel employs begin-end transformation for the purpose of creating isomorphic musical transformations within the text. ${ }^{35}$ For example, in the beginning state, the child is naughty and he goes against Maman's ('Mother's') wishes through his destructive rampage against the animals and objects in the house. As seen in Appendix F, in this scene, a series of transpositions convey the opposition between the mother and child. ${ }^{36}$ The progressively higher transpositions of Mother's cadence (MC) reflect the child's willful silence in response to his mother's queries and also her mounting displeasure. ${ }^{37}$ The scene concludes with a final statement of Mother's cadence in the original pitch, giving the last word to Maman. ${ }^{38}$ There is an isomorphic representation in the music where the untransposed MC conveys the mother's unshakeable moral authority. ${ }^{39}$ After the child's rampage in the room, the animals and objects come to life and reveal to the child the consequences of his behaviour. In the last stage, the child embraces Maman and morality. The child's transformation is complete as he sings Maman accompanied by MC. ${ }^{40}$ The MC as a perfect cadence communicates the strength and finality of Maman's will, and the child's submission to it. ${ }^{41}$ Here, the accompaniment by the MC

33 ibid., p. 10.

34 ibid., p. 12.

35 Peter Kaminsky, 'Of Children, Princesses, Dreams and Isomorphisms: Text-music Transformations in Ravel's Vocal Works', Musical Analysis, 19/1 (2000), p. 32.

36 'Transposition' refers to 'the notation or performance of music at a pitch different from that in which it was originally conceived or notated, by raising or lowering all the notes in it by a given interval.' Julian Rushton, 'Transposition', Grove Music Online, Oxford Music Online, Oxford University Press, accessed 29 October 2013, http://www.oxfordmusiconline.com/subscriber/article/grove/music/28274.

37 'The Mother's cadence' (MC) refers to the ambiguous cadential figure during the last restatement of the prelude that immediately precedes the entrance of Maman. See Appendix E for more detailed analysis. 'Cadence' refers to 'the conclusion to a phrase, movement or piece based on a recognizable melodic formula, harmonic progression or dissonance resolution; the formula on which such a conclusion is based'. William S. Rockstro, et al., 'Cadence', Grove Music Online. Oxford Music Online. Oxford University Press, accessed 29 October 2013, http://www.oxfordmusiconline.com/subscriber/article/grove/music/04523.

38 ibid.

39 ibid, p. 41. See Appendix I to see the child's transformation.

40 ibid.

41 ibid. 
isomorphically represents the child's acceptance of Maman's moral authority. Ravel's composition method creates the musical and dramatic effects to convey the meaning and emotion in the text. For example, Maman's cadence serves as the agent for the child's transformation from bad to good. Although Maman is not literally present on stage, her cadence is restated in each opening and closing scene with musical changes in key, orchestration and chord to create different dramatic musical effects that relate to the developing plot. The isomorphic musical transformations in L'Enfant are important in communicating Colette's writing. Conversely, without Colette's words, the isomorphic associations and meaning would be absent from the music. Ravel's unique composition technique clearly demonstrates the close relationship that music has with the text in representing the meaning and structure of the work.

In conclusion, through exploring the genesis of L'Enfant, studying Ravel's manipulation of the rhymes and rhythms of Colette's libretto, the relationship $L^{\prime}$ Enfant has with fairytale narratives, and Ravel's unique composition technique, there is much evidence to support the argument that, despite the lack of recorded correspondence between the composer and librettist during 1916-25, $L^{\prime} E n f a n t$ was nonetheless the result of a genuine collaboration between Ravel and Colette. As Ravel said himself, the nature of collaboration in L'Enfant lies between the 'keen' artistic sympathies shared by the two individuals. ${ }^{42}$ While they worked in different métiers, both Ravel and Colette were storytellers, and it is in this act of storytelling that Ravel and Colette best expressed their keen artistic sympathy.

\section{Appendix A - The first known direct communication between the collaborators; 43 Ravel to Colette on 27 February 1919.}

February 27, 1919

Dear Madame,

While you were expressing your regrets to Rouché about my silence, I was thinking, amid all the snow, of asking you if you still wanted such an unreliable collaborator.

My only excuse is the state of my health: for a long time, I feared that I would never be able to do anything. It appears that I'm improving: the desire to work seems to be returning. Here, it's not possible; but as soon as I return, at the beginning of April, I'm planning to resume work, and will begin with our opera.

42 Orenstein, A Ravel Reader, p. 188.

43 Kilpatrick, 'Enchantments and Illusions', p. 36. 
In truth, I am already working on it: I'm taking notes — without writing any —;

I'm even thinking of some modifications ... Don't be afraid: they're not cuts - on the contrary. For example: couldn't the squirrel's dialogue be extended? Imagine everything that a squirrel could say about the forest, and how that could be interpreted in music!

Another thing: what would you think of the cup and teapot, in old Wedgwood — black - singing a ragtime? I confess that the idea of having a ragtime sung by two Negroes at our National Academy of Music fills me with great joy. Note that the form - a single couplet, with refrain - would be perfectly suited to the gestures in this scene: complaints, recriminations, furor, pursuit. Perhaps you will object that you don't usually write American Negro slang. I, who don't know a word of English, will do just like you: I'll work it out.

I would be grateful to have your opinion on these two points, and, dear Madame, believe in the keen artistic sympathy of yours truly,

Maurice Ravel

Source: Arbie Orenstein, A Ravel Reader: Correspondence, Articles, Interviews, Mineola, New York: Dover Publications, 2003, p. 188.

\title{
Appendix B - Colette's response to Ravel on 5 March 1919
}

\author{
March 5, 1919
}

69 Boulevard Suchet

Paris XVI

Dear Sir,

Why certainly a ragtime! Why of course Negroes in Wedgwood! What a terrific gust from the music hall to stir up the dust of the Opéra! Go to it! I am glad to know that you are still thinking of 'Divertissement for my Daughter'. I despaired of you, and was told that you were sick. Do you know that orchestras in cinema houses are playing your charming Mother Goose suite, while they show American westerns? If I were a composer and Ravel, I think I would derive much pleasure from learning that.

And the squirrel will say everything you wish. Does the 'cat' duo, exclusively meowed, please you? We'll get acrobats. Isn't the Arithmetic business a polka? 
I wish you good health, and shake your hand impatiently.

Colette de Jouvenel

Source: Orenstein, Arbie. A Ravel Reader: Correspondence, Articles, Interviews, Mineola, New York: Dover Publications, 2003, p. 188.

\section{Appendix C - The sortilèges are grouped according to their vowel and consonant sounds into two categories:}

\begin{tabular}{|c|c|}
\hline $\begin{array}{l}\text { Sortilèges characters with 'hard' vowel and consonant } \\
\text { sounds }\end{array}$ & $\begin{array}{l}\text { Sortilèges characters with 'soft' } \\
\text { vowel and consonant sounds }\end{array}$ \\
\hline $\begin{array}{l}\text { The child's opening monologue, the clock, the } \\
\text { arithmetic scene, the rire and the teapot. }\end{array}$ & $\begin{array}{l}\text { The princess, the cats, the } \\
\text { dragonfly and the squirrel. }\end{array}$ \\
\hline $\begin{array}{l}\text { Examples: } \\
\text { Make more use of the hard 'a' and incisive 'e' vowels, } \\
\text { together with the consonant sounds } \mathrm{f}, \mathrm{t} \text { and } \mathrm{z} \text {. } \\
\text { 1) The child sings 'J'ai pas envie de faire mapage' } \\
\text { 2) The teapot's scene opens with the line 'Black and } \\
\text { costaud, black and chic ...' }\end{array}$ & $\begin{array}{l}\text { Examples: } \\
\text { Make more use of 'soft' sounds: } \\
\text { the consonants b/d/g, the fricative } \\
z \text { [rose], the light i [libre] and } \varepsilon \\
\text { [aime and cherche], and the slow } \\
\theta \text { [jeu] œ [coeur] and o [rose] } \\
\text { vowels. } \\
\text { 1) The squirrel sings 'mes beaux } \\
\text { yeux' } \\
\text { 2) The dragonfly's line 'Je te } \\
\text { cherche' }\end{array}$ \\
\hline
\end{tabular}

Source: Emily Kilpatrick, “'Jangling in Symmetrical Sounds”: Maurice Ravel as Storyteller and Poet', Music Council of Australia, 1 (2009), p. 11.

\section{Appendix D - The contrast between these two linguistic affects can be seen in comparison of the fire's libretto with the dragonfly's.}

\begin{tabular}{|l|l|}
\hline [The Fire] & [The Dragonfly] \\
\hline Je rechauffe les bonsJe brûle les méchantsPetit & Où es tu?Je te chercheLe filetll t'a \\
barbare, barbare imprudentTu as insultéàtous les & priseO toi chèreLongue et frèleTes \\
dieux bienveillantQuitendent entre le malheur et & turquoises Tes topazesL'air qui \\
toiLe fragile barrière!...Gare au feu dansant!Gare, & t'aimeLes regretteMoins que moi... \\
gare, gare, gare à toi! & \\
\hline
\end{tabular}

Source: Emily Kilpatrick, “'Jangling in Symmetrical Sounds”: Maurice Ravel as Storyteller and Poet', Music Council of Australia, 1 (2009), p. 11. 


\section{Appendices E - I: A musical analysis of the child's development through three stages.}

\section{Appendix E: Pentatonic variations and 'moral choice'}

Ex. 2 L'enfant et les sortilèges

a) Pentatonic variations and 'moral choice'
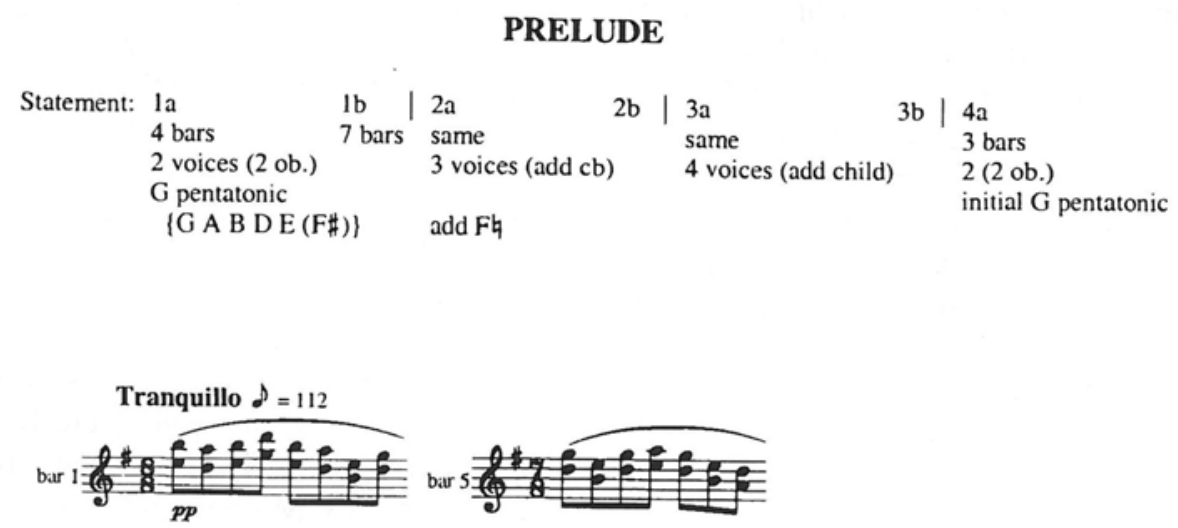

Figure 1 : Pentatonic variations and 'moral choice'

Source: Peter Kaminsky, 'Of Children, Princesses, Dreams and Isomorphisms: Text-Music Transformations in Ravel's Vocal Works', Musical Analysis, 19/1 (2000), p. 39.

As suggested by the innocent sound of two oboes, the openness of the parallel 5 th and 4 th, and the tonal neutrality of the pentatonic pitch collection $(\mathrm{G}-\mathrm{A}-\mathrm{B}-$ $\mathrm{D}-\mathrm{E}-[\mathrm{F} \#])$, it may be said that the music conjures up a world of moral possibilities and choices to the young child. Three restatements of the prelude are given and, during the last restatement, there is an interruption by an ambiguous cadential figure. This immediately precedes the entrance of Maman and it can be known as MC (mother's cadence). 


\section{Appendix F- Maman's moral authority and the child's disobedience}
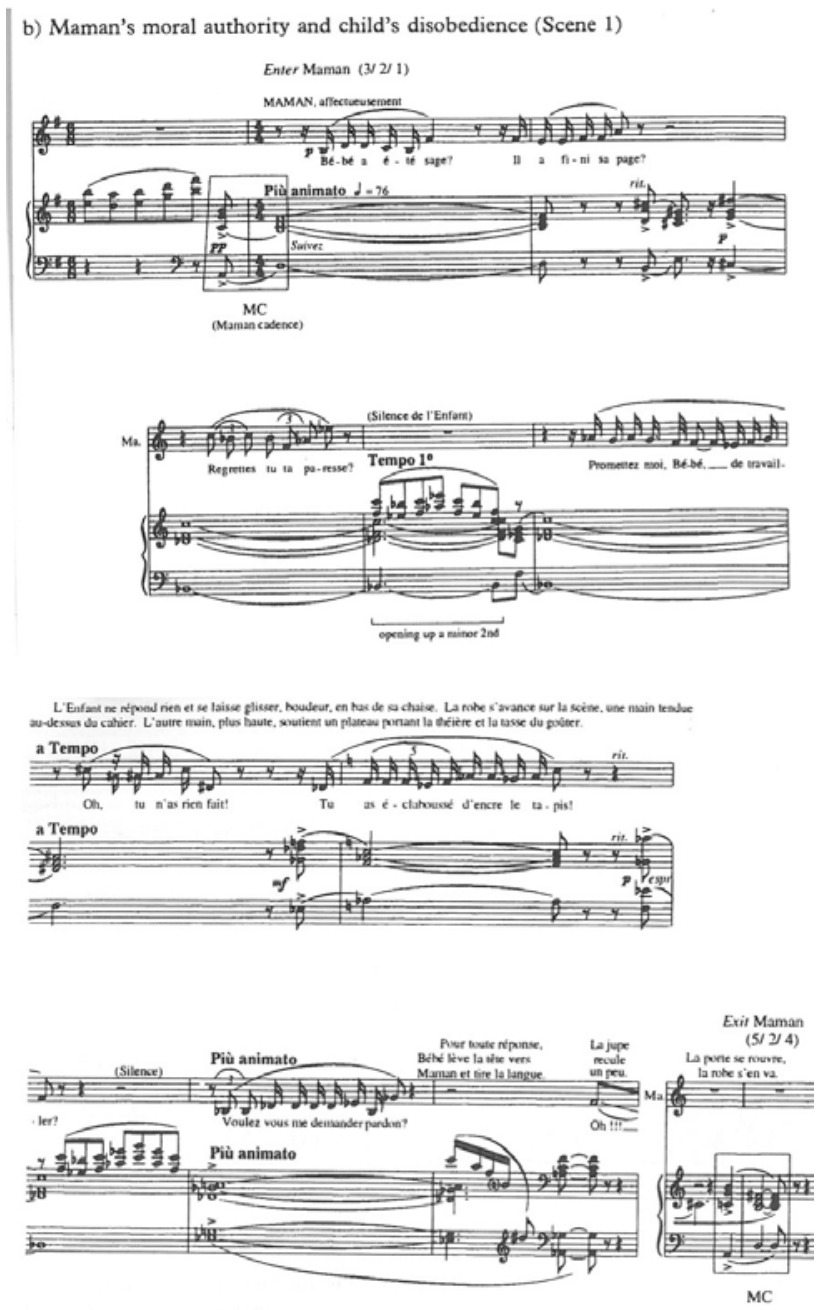

Figure 2: Maman's moral authority and the child's disobedience

Source: Peter Kaminsky, 'Of Children, Princesses, Dreams and Isomorphisms: Text-Music Transformations in Ravel's Vocal Works', Musical Analysis, 19/1 (2000), pp. 40-41. 


\section{Appendix G - The penultimate scene prior to the child's actual transformation stage 1}

Ex. 2 (continued)

c) Maman's cadence, tonal context, child's transformation - stage 1

FINAL

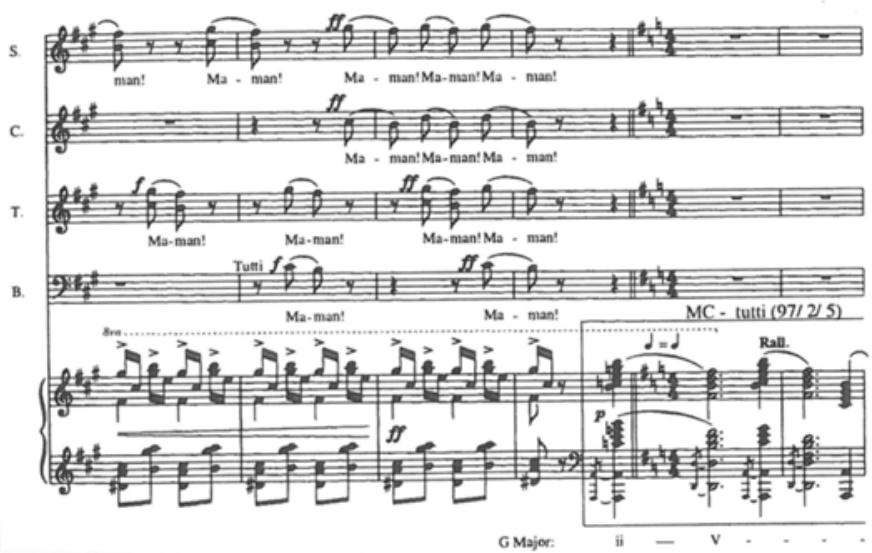

SCENE
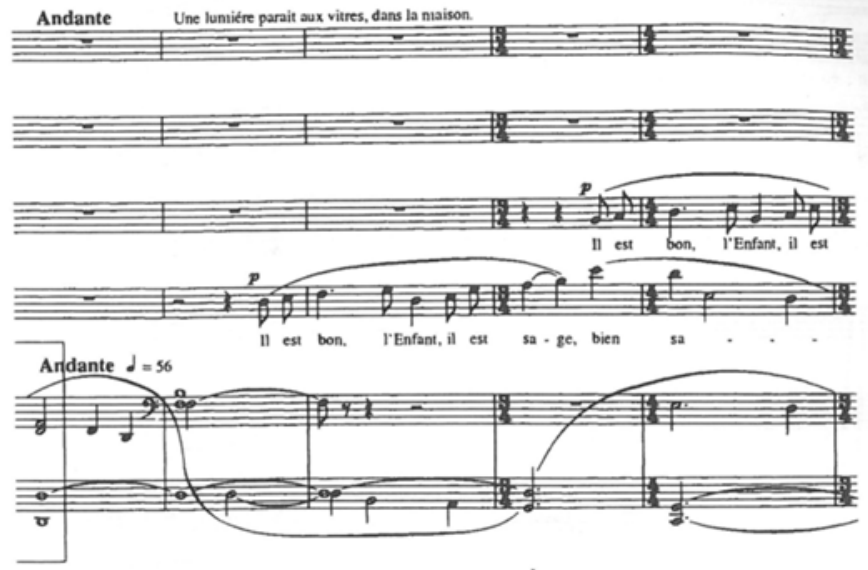

Figure 3: The penultimate scene prior to the child's actual transformation stage 1

Source: Peter Kaminsky, 'Of Children, Princesses, Dreams and Isomorphisms: Text-Music Transformations in Ravel's Vocal Works', Musical Analysis, 19/1 (2000), pp. 42-43.

In this scene, the animals bear witness to the child's goodness, but they are powerless to dress the child's wound. They realise that only Maman can heal the child, and they call for her: 'Maman! Maman! Maman!' Although not literally present on the stage, Maman makes a dramatic return via the MC. Some musical 
changes in the MC include: a different orchestration and the cadence has a definite tonal context - functioning as ii- $\mathrm{V}$ in $\mathrm{G}$ major and resolving to the tonic, coinciding with 'Il est bon.' 'This suggests that through this change in the tonal context, the latent moral authority associated with MC at its original pitch level is actualized; communicating the story and meaning of the work.'

\section{Appendix $\mathrm{H}$ - Prelude's reprise, counterpoint, child's transformation - stage 2}

d) Prelude's reprise, counterpoint, child's transformation - stage 2

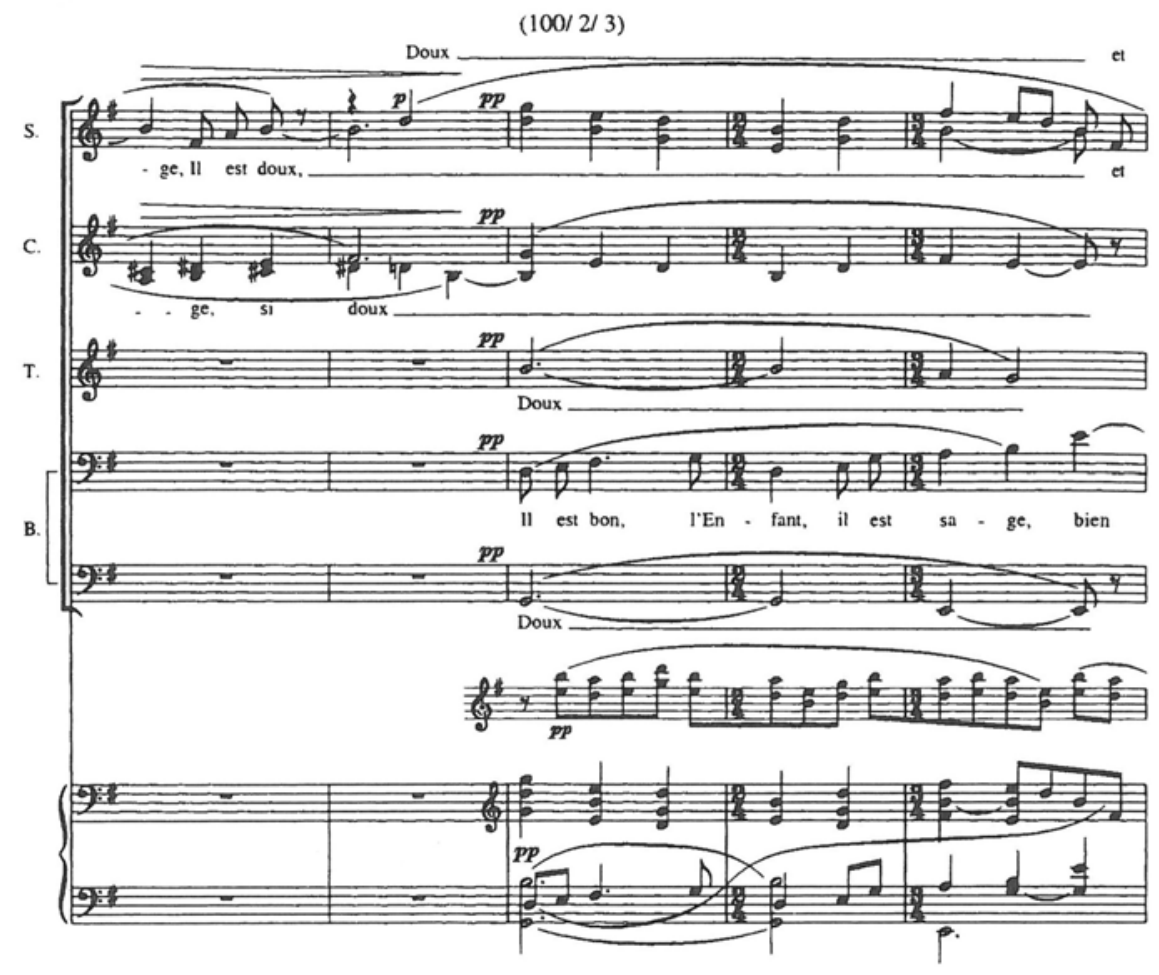

Figure 4: Prelude's reprise, counterpoint, child's transformation - stage 2

Source: Peter Kaminsky, 'Of Children, Princesses, Dreams and Isomorphisms: Text-Music Transformations in Ravel's Vocal Works', Musical Analysis, 19/1 (2000), p. 44.

As the innocent opening statement of the prelude (two oboes) returns in its complete and unaltered form, the child's embrace of morality starts to manifest. Only now, it is grounded in the tonic G major and combined with the second statement of 'Il est bon.' 
In a metaphoric way, throughout the opera, the morally neutral child progresses in the light of experience and this leads him to become good. There is an isomorphic representation here: the prelude's tonal neutrality gives way to it confirming to the norms of the tonal system - therefore tonality itself represents moral code.

This example also demonstrates the close music-text relationship in L'Enfant and the collaboration between Ravel and Colette.

\section{Appendix I - Continuation of stage 2 and the completion of the child's transformation at 'Maman!'}

e) Maman's cadence, child's embrace, final transformation

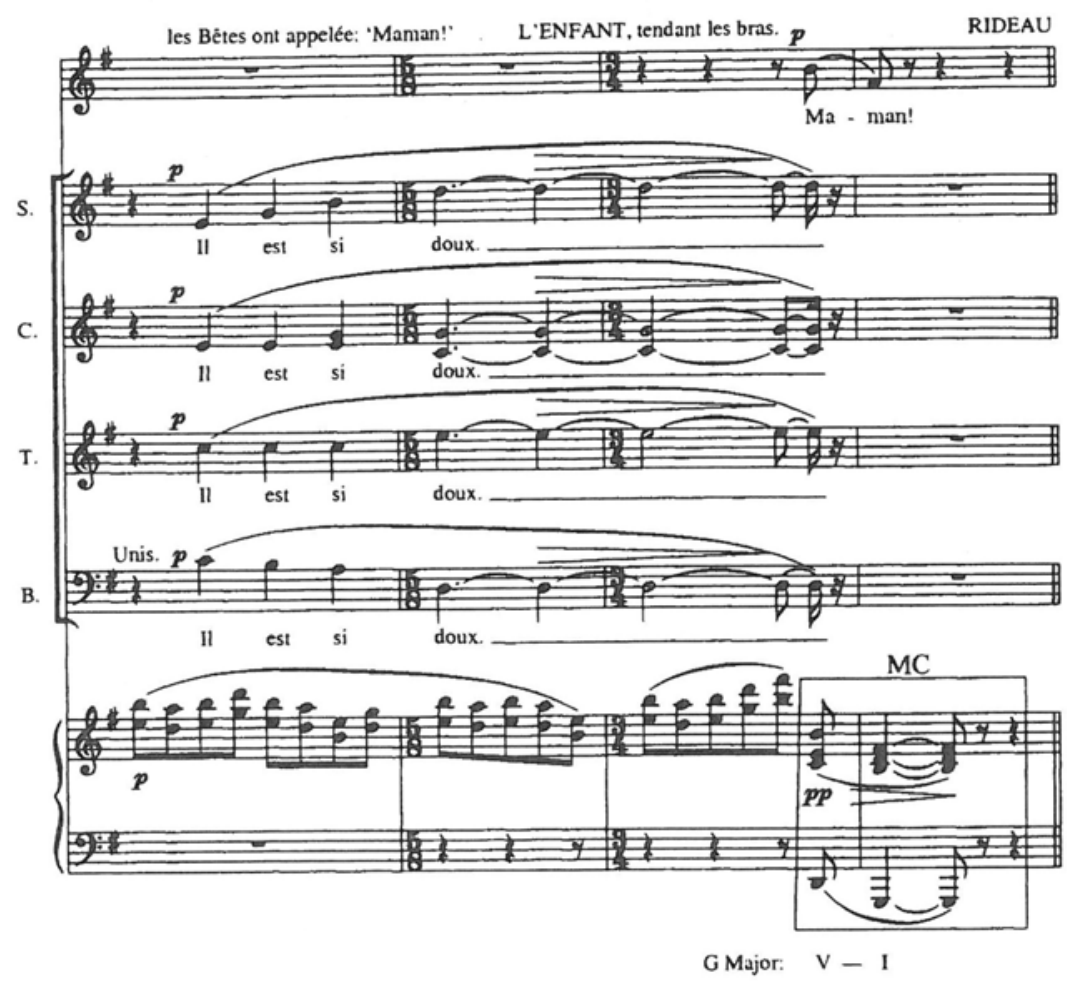

Figure 5: Continuation of stage 2 and the completion of the child's transformation at 'Maman!'

Sourece: Peter Kaminsky, 'Of Children, Princesses, Dreams and Isomorphisms: Text-Music Transformations in Ravel's Vocal Works', Musical Analysis, 19/1 (2000), p. 45. 


\section{Bibliography}

Jankélévitch, Vladimir, Ravel, Translated by Margaret Crosland, Westport, Conn: Greenwood Press, 1976.

Kamien, Roger, Music An Appreciation, New York: McGraw-Hill, 2004.

Kaminsky, Peter, 'Of Children, Princesses, Dreams and Isomorphisms: TextMusic Transformations in Ravel's Vocal Works', Musical Analysis, 19/1 (2000), pp. 29-67.

- Unmasking Ravel: New Perspectives on the Music, Rochester, New York: University of Rochester Press, 2011.

Kelly, Barbara L., 'Ravel, (Joseph) Maurice', Grove Music Online, Oxford Music Online, Oxford University Press, accessed 29 October 2013, http://www. oxfordmusiconline.com/subscriber/article/grove/music/52145.

Kilpatrick, Emily, 'Into the Woods: Retelling the Wartime Fairytales of Maurice Ravel', Musical Times 149, no. 1902 (2008), pp. 57-66.

- ' "Jangling in Symmetrical Sounds": Maurice Ravel as Storyteller and Poet', Music Council of Australia, 1 (2009), pp. 1-19.

- 'Enchantments and Illusions: Recasting the Creation of L'Enfant et lest sortileges', in Deborah Mawer, Ravel Studies, Cambridge University Press, 2010.

Myers, Rollo H., Ravel: Life and Works, London: Duckworth, 1971.

Nichols, Roger. 'Enfant et les sortilèges, L', The New Grove Dictionary of Opera. Grove Music Online. Oxford Music Online. Oxford University Press, accessed 29 October 2013, http://www.oxfordmusiconline.com.virtual.anu.edu.au/ subscriber/article/grove/music/0003509.

_ The Master Musicians: Ravel, London: JM Dent, 1977.

- Ravel, New Haven: Yale University Press, 2011.

Orenstein, Arbie, Ravel: Man and Musician, New York: Columbia University Press, 1975.

- A Ravel Reader: Correspondence, Articles, Interviews, Mineola, New York: Dover Publications, 2003.

Rushton, Julian, 'Transposition', Grove Music Online. Oxford Music Online. Oxford University Press, accessed 29 October 2013, http://www.oxfordmusiconline. com/subscriber/article/grove/music/28274. 
Rockstro, William S. et al., 'Cadence', Grove Music Online. Oxford Music Online. Oxford University Press, accessed 29 October 2013, http://www. oxfordmusiconline.com/subscriber/article/grove/music/04523.

Smith, Richard L., 'Colette', The New Grove Dictionary of Opera, Grove Music Online, Oxford Music Online, Oxford University Press, accessed 29 October 2013, http://www.oxfordmusiconline.com/subscriber/article/grove/music/ O005396.

_.., 'Ravel's Operatic Spectacles', in Jonathan Cross \& Deborah Mawer, The Cambridge Companion to Ravel, New York: Cambridge University Press, 2000.

Tilmouth, Michael, 'Act', Grove Music Online. Oxford Music Online. Oxford University Press, accessed 28 October 2013, http://www.oxfordmusiconline. com/subscriber/article/grove/music/00140.

Warrack, John \& Chalmers, Kenneth. 'libretto', The Oxford Companion to Music. Oxford Music Online. Oxford University Press, accessed October 29, 2013, http://www.oxfordmusiconline.com/subscriber/article/opr/t114/e3957.

Zank, Stephen, Maurice Ravel: A Guide to Research, New York: Routledge, 2005. 
This text taken from The ANU Undergraduate Research Journal Volume Five 2013, published 2014 by ANU Press, The Australian National University, Canberra, Australia. 